University of Nebraska - Lincoln

DigitalCommons@University of Nebraska - Lincoln

2011

Plant Community Recovery Following Restoration in Semiarid Grasslands

Seth M. Munson

Colorado State University, smunson@usgs.gov

William K. Lauenroth

University of Wyoming, wlauenro@uwyo.edu

Follow this and additional works at: https://digitalcommons.unl.edu/usgsstaffpub

Munson, Seth M. and Lauenroth, William K., "Plant Community Recovery Following Restoration in Semiarid Grasslands" (2011). USGS Staff -- Published Research. 607.

https://digitalcommons.unl.edu/usgsstaffpub/607

This Article is brought to you for free and open access by the US Geological Survey at DigitalCommons@University of Nebraska - Lincoln. It has been accepted for inclusion in USGS Staff -- Published Research by an authorized administrator of DigitalCommons@University of Nebraska - Lincoln. 


\title{
Plant Community Recovery Following Restoration in Semiarid Grasslands
}

\author{
Seth M. Munson ${ }^{1,2,3,4}$ and William K. Lauenroth ${ }^{5}$
}

\begin{abstract}
The Conservation Reserve Program (CRP) is an extensive land use in the United States, which restores cultivated land to perennial vegetation through seeding. Low precipitation and high potential evapotranspiration are major limitations to the establishment and growth of seeded species in semiarid regions. We tested the rate of development of plant functional types across a chronosequence of restored fields using a model of plant succession. We also determined how the seeding of non-native (introduced) relative to native perennial grasses influenced plant community recovery. In contrast to the native shortgrass steppe (SGS), recently seeded CRP fields had high cover of annuals, forbs, $\mathrm{C}_{3}$, and introduced species. The seed mix determined which perennial grasses dominated the plant community within 18 years, but slow establishment prolonged early seral stages, allowed for the spread of colonizing perennial
\end{abstract}

grasses, and limited recovery to less than half the canopy cover of undisturbed shortrass steppe. Species density declined in restored fields as seeded perennial grass cover increased and was lower in CRP fields seeded with introduced compared to native perennial grasses. Plant community composition transitioned to $C_{4}$ and native species, even if fields were not seeded with these species, and was modified by shifts in the amount and seasonality of precipitation. Thus, in semiarid CRP fields, we found that the potential for recovery depended on time since CRP enrollment, seed mix, and climatic variability. Full recovery, based on similarity to vegetation cover and composition of undisturbed SGS, requires greater than 20 years.

Key words: Conservation Reserve Program, cultivation, disturbance, perennial grass, plant functional type, shortgrass steppe, succession.

\section{Introduction}

The spatial and temporal dynamics of plant community composition are influenced by disturbance, which disrupts community structure (White \& Pickett 1985). Dryland (non-irrigated) wheat cropping is an extensive land use in the Western United States and throughout the world. In eastern Colorado, the driest portion of the U.S. Great Plains, this land use utilized over 1 million hectares of former shortgrass steppe (SGS) during 2007 (USDA National Agricultural Statistics Service 2010). Tillage practices in these cropping systems destroy above and belowground plant components at the field scale, unlike drought and grazing, to which shortgrass species have adapted (Milchunas et al. 1988). Seeding the field with an annually harvested crop replaces the diverse perennial grasses, herbaceous dicots, subshrubs, and cacti. Cultivation also has indirect

\footnotetext{
${ }^{1}$ Department of Forest, Rangeland, and Watershed Stewardship, Colorado State University, Fort Collins, CO 80523, U.S.A.

${ }^{2}$ Graduate Degree Program in Ecology, Colorado State University, Fort Collins, CO 80523, U.S.A.

3 Address correspondence to S. M. Munson, email smunson@usgs.gov

${ }^{4}$ Current address: USGS-Southwest Biological Science Center, Canyonlands Research Station, 2290 S. West Resource Blvd., Moab, UT 84532, U.S.A.

5 Department of Botany and Program in Ecology, University of Wyoming,

Laramie, WY 82071, U.S.A.

(C) 2011 Society for Ecological Restoration International

doi: 10.1111/j.1526-100X.2011.00808.x
}

effects on plant community composition through alteration of the physical and chemical characteristics of the soil.

After disturbance, restoration practices can modify the trajectory of natural succession. The Conservation Reserve Program (CRP) is an extensive land use that was initiated in 1985 by the U.S. Food Security Act (USDA Farm Service Agency 2010). Like many agricultural incentive programs throughout the world, CRP pays farmers to convert their cultivated land to perennial vegetation and currently includes nearly 1 million hectares in eastern Colorado. Although CRP has been implemented over the last 25 years at a national scale, very little is known about how CRP practices contribute to recovery of plant community composition. In eastern Colorado, semiarid CRP lands are seeded with perennial grasses, which can restore vegetation cover and composition to resemble undisturbed SGS (Coffin et al. 1996). However, low precipitation and high potential evapotranspiration can limit recovery through their influence on soil moisture. Another limitation to recovery is that CRP seed mixes can contain introduced species that are not native to eastern Colorado, which may suppress native plant species and result in a plant community that is compositionally very different from undisturbed SGS.

To better understand recovery in CRP fields, we constructed a conceptual model of plant community dynamics to account for perennial grasses in the CRP seed mix by modifying 


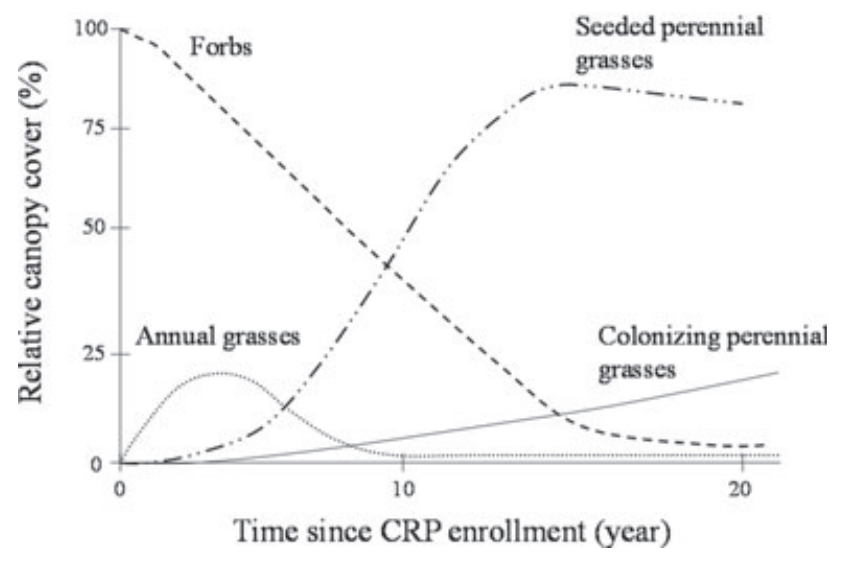

Figure 1. Conceptual model of plant community dynamics on CRP fields (modified from Coffin et al. 1996), which shows the trajectory of plant functional types (forbs, annual grasses, seeded perennial grasses, and colonizing perennial grasses) through time since CRP enrollment.

old-field successional models developed in the SGS (Judd \& Jackson 1939; Costello 1944; Coffin et al. 1996). Similar to previous models, our model includes trajectories for annual grasses and forbs immediately following the cessation of cropping, but also illustrates how these plant functional types are replaced by seeded and colonizing perennial grasses (Fig. 1). Colonizing perennial grasses disperse from neighboring fields, with short-lived species establishing before long-lived shortgrasses (Savage \& Runyon 1937). We used the model to test the rate of development and the duration of persistence of each of these functional types.

Our objective was to determine how well CRP restoration practices recovered plant community composition compared to undisturbed SGS and to understand the controls of plant community variability in these fields. Specifically, we addressed the following questions:

(1) How does time since CRP enrollment affect plant community composition in restored fields?

(2) How does seed mix affect plant community composition in restored fields?

(3) How does environmental variability affect interannual change in plant community composition in restored fields and undisturbed SGS?

\section{Methods}

\section{Study Sites}

Our study was conducted at undisturbed SGS sites within the Central Plains Experimental Range (CPER, SGS Long Term Ecological Research site) located $60 \mathrm{~km}$ northeast of Fort Collins, Colorado $\left(40^{\circ} 49^{\prime} \mathrm{N}, 107^{\circ} 47^{\prime} \mathrm{W}\right)$, and CRP sites (herein referred to as fields) located within $13 \mathrm{~km}$ to the south and $3 \mathrm{~km}$ to the west of the CPER. The climate is semiarid with a long-term (1969-2007) mean annual precipitation of $332 \mathrm{~mm}(\mathrm{SE}=16 \mathrm{~mm}), 80 \%$ of which falls between April and September, and a mean annual temperature of $9.6^{\circ} \mathrm{C}$ $\left(\mathrm{SE}=0.2^{\circ} \mathrm{C}\right.$ ). Undisturbed SGS is dominated by the $\mathrm{C}_{4}$ perennial grasses Bouteloua gracilis and Buchloë dactyloides (plant nomenclature follows Great Plains Flora Association 1986). Other important functional types included $\mathrm{C}_{3}$ graminoids, forbs, dwarf shrubs, and prickly pear cactus. SGS sites had been long-term moderately summer grazed (0.5 AUM/ha), but this treatment does not have a long-term effect on plant community composition (Milchunas et al. 1988) and sites were excluded from grazing during the study. These sites did not experience fire or any other disturbance prior to the study.

We partitioned CRP fields into those seeded with perennial grasses that occur in eastern Colorado (native) and those seeded with perennial grasses that are not native to eastern Colorado (introduced). The native seed mix contained Agropyron smithii (approximately 30\% weight of all seed), Bo. gracilis (approximately 20\%), Bo. curtipendula (approximately 20\%), other perennial grasses (approximately 20\%), and Dalea purpurea (approximately 10\%). The introduced seed mix contained either 100\% Bromus inermis (BRIN) or $100 \%$ A. intermedium (AGIN). To address time since CRP enrollment, we established a chronosequence that consisted of three field age classes: early (2-4 years after CRP enrollment), mid ( $7-9$ years), and late (18-20 years). All fields in the chronosequence were seeded with a native seed mix to minimize differences in the potential vegetation. We replicated each of the six field types (undisturbed SGS; early, mid, and late CRP fields seeded with a native seed mix; and late CRP fields seeded with either introduced BRIN or AGIN) three times for a total of 18 fields sampled ( 6 field types $\times 3$ field replicates $=18$ fields sampled). All field replicates were within a $170 \mathrm{~km}^{2}$ area and spaced $1-15 \mathrm{~km}$ of each other. We sampled each field for 3 years to account for environmental variability. To address differences in seed mix, we compared late CRP fields seeded with native perennial grasses to late CRP fields seeded with introduced perennial grasses.

All fields were in a non-irrigated wheat-fallow rotation prior to CRP enrollment. The year of CRP enrollment, fields were seeded with a sterile sorghum cover crop to protect the seedbed and discourage annual weeds (Natural Resources Conservation Service 1991). A year later, fields were doubledisked and drill seeded to a $1.3 \mathrm{~cm}$ depth with perennial grasses (approximately $0.5 \mathrm{~g} / \mathrm{m}^{2}$ seed) and $20 \mathrm{~cm}$ spacing between rows. Surface soil $(0-5 \mathrm{~cm})$ textures were loamy sand, sandy loam, and sandy clay loam. All SGS sites and CRP fields had a similar topographic relief ( $<3 \%$ slope).

\section{Sampling Methods}

We sampled species composition in forty $0.25 \mathrm{~m}^{2}$ circular quadrats in each field in late August to early September 2005, 2006, and 2007. Quadrats were spaced $20 \mathrm{~m}$ apart along five evenly spaced transects and occurred a minimum of $100 \mathrm{~m}$ from the field edge to minimize edge effect. We estimated canopy cover class $(0-1,1-5,5-15,15-25,25-40,40-60$, $60-100 \%)$ by species. Because of the early senescence of Br. tectorum, an introduced winter annual grass, we separately 
Table 1. Annual and seasonal precipitation (mm) from 2005 to 2007 and 38-year means.

\begin{tabular}{lrrr}
\hline Year & 2005 & 2006 & 2007 \\
\hline Annual precipitation (January to December) & 370 & 301 & 409 \\
Early growing season precipitation (April to June) & 202 & 54 & 52 \\
Late growing season precipitation (July to September) & 53 & 144 & 224 \\
\hline
\end{tabular}

estimated its canopy cover in early June. The relative percent canopy cover of each species (averaged across all years of study, 2005-2007) in each field type are provided in Appendix S1 (Supporting Information).

\section{Statistical Analyses}

Our analyses used the average canopy cover of each species in each field. We grouped species according to life form (grass, forb, cactus, and subshrub) to represent important reproductive and structural traits that can influence recovery in the SGS (Vinton \& Burke 1995). We grouped grasses and forbs according to their lifespan (annual and perennial), and perennial grasses were further grouped according to whether or not they naturally colonized or were seeded. We also analyzed species according to photosynthetic pathway $\left(\mathrm{C}_{3}, \mathrm{C}_{4}\right.$, and CAM) and according to whether or not they were native to eastern Colorado (native and introduced). We calculated species density by taking the average number of species in a $0.25 \mathrm{~m}^{2}$ quadrat in each field. We performed repeated measures analysis of variance on the canopy cover of plant functional types and species density with field type as the main effect and year as the repeated measure modeled with autoregressive correlation structure (Proc Mixed; SAS 9.2, SAS Institute Inc. 2002-2008, Cary, NC, U.S.A.). Canopy cover data were arcsine square root transformed to meet assumptions of normality and homogeneity of variance. We used a Tukey multiple comparison adjustment when comparing field types separately for each year and years separately for each field type (Proc Glimmix; SAS, June 2006 release).

We performed linear and nonlinear regression on canopy cover of functional types across time since CRP enrollment for all fields in the chronosequence (Proc Reg; SAS 9.2). Regressions were performed using canopy cover from individual years, not age classes, to collectively account for successional change and interannual variability in all CRP fields in the chronosequence. We report the coefficient of determination $\left(r^{2}\right)$ to explain the amount of variance in canopy cover of functional types explained by time since CRP enrollment, but the $p$-value was not accurate because the regression was performed on untransformed data. We performed additional regressions between different functional types, as well as species density and annual precipitation to assess how the biotic and abiotic environments influenced recovery dynamics.

\section{Results}

Both inter- and intra-annual variability in precipitation was high during the study. Annual precipitation ranged from
$301 \mathrm{~mm}$ in 2006 to $409 \mathrm{~mm}$ in 2007 (Table 1). Early growing season precipitation in 2005 was $42 \%$ above the long-term mean and late growing season precipitation was $57 \%$ below the mean. In contrast, early growing season precipitation in 2006 and 2007 was 62 and $42 \%$ below the mean and late growing season precipitation was 16 and $81 \%$ above the mean, respectively.

Canopy cover of species and functional types were significantly affected by time since CRP enrollment and seed mix. Annual and perennial forb cover was high in the early CRP fields, decreased as time since CRP enrollment increased (collectively $0.86 \%$ per year, Fig. $2 \mathrm{a}$ ), and were inversely correlated to perennial grass canopy cover across all CRP fields in the first 2 years of the study $(r=-0.77, p=0.0002)$. Both these functional types had high interannual variability. Annual forb cover was on average $86 \%$ of total forb cover in CRP fields. Forb cover in late CRP fields seeded with native perennial grasses was not significantly different from late CRP fields seeded with introduced perennial grasses or undisturbed SGS for the first 2 years of the study.

Annual grass canopy cover increased and reached a peak of $39 \% 7$ years after CRP enrollment before declining to almost no cover after 18 years (Fig. 2b). This increase was almost entirely due to the introduced winter annual, Bromus tectorum, which had high spatial and temporal variability in cover. Other annual grasses had high cover in early CRP fields and were nearly absent in mid CRP fields. All annual grass cover in late CRP fields seeded with native perennial grasses was less than $1 \%$ in all sampling years and was not significantly different from either of the late CRP fields seeded with introduced perennial grasses or undisturbed SGS.

Seeded perennial grass canopy cover increased $1.3 \%$ per year along the chronosequence (Fig. 2c). Seeded perennial grass cover approached $30 \%$ in late CRP fields seeded with native perennial grasses, which was not significantly different from either of the late CRP fields seeded with introduced perennial grasses for all sampling years. However, seeded perennial grass canopy in CRP fields was significantly lower than perennial grass cover in undisturbed SGS for all sampling years.

Colonizing perennial grass cover increased $0.50 \%$ per year along the chronosequence, but was near zero for the first 4 years of CRP enrollment (Fig. 2d). Late CRP fields seeded with introduced perennial grasses were not significantly different from late CRP fields seeded with native perennial grasses in colonizing perennial grass cover for all sampling years, but increased in cover during the study. Interannual variability was low for seeded and colonizing perennial grasses relative to forbs and annual grasses. Dwarf shrubs and cacti 


\section{Field Type}

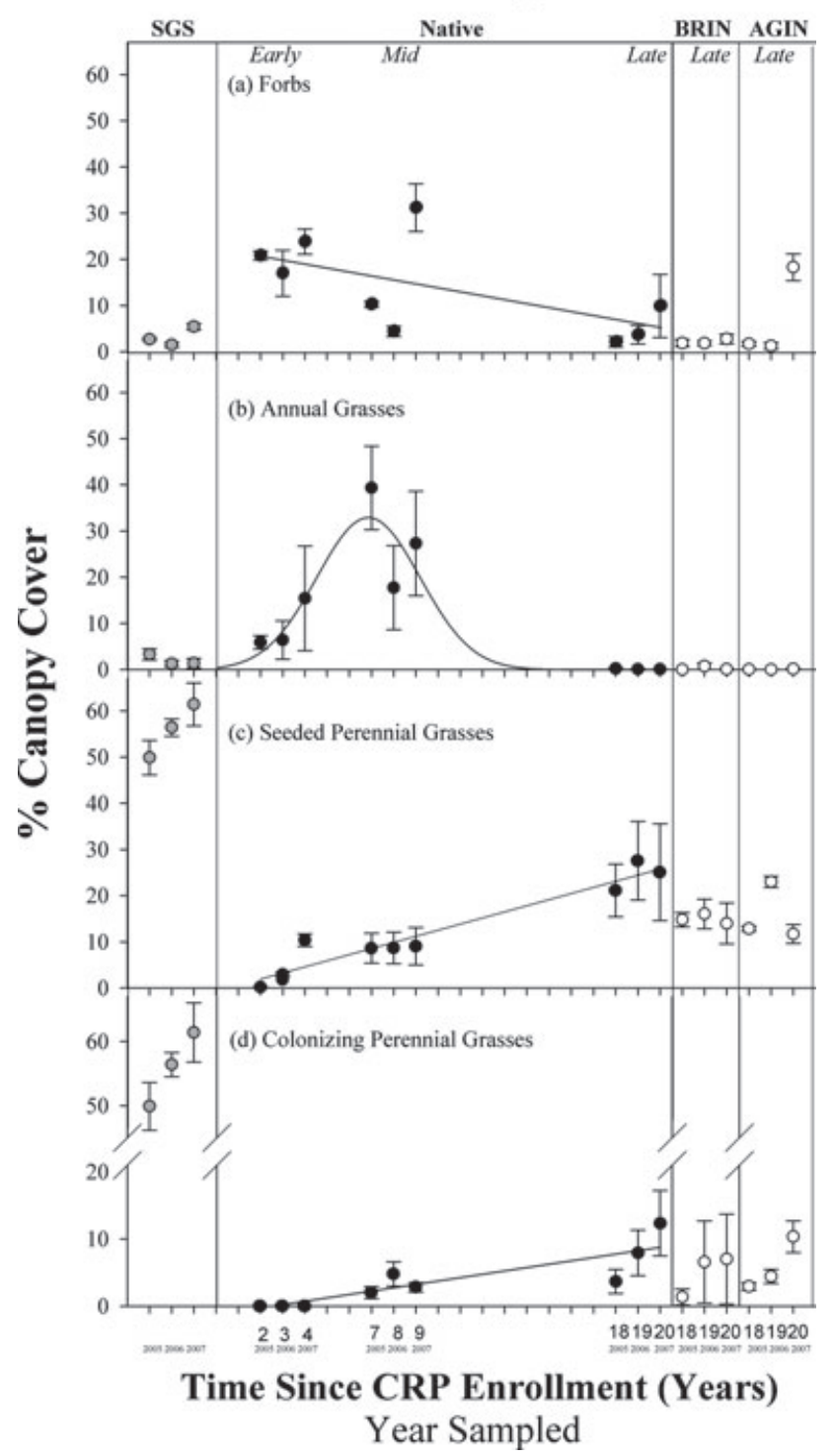

Figure 2. Mean percent canopy cover ( \pm SE) of forbs (a), annual grasses (b), seeded perennial grasses (c), and colonizing perennial grasses (d) in SGS, and in relation to time since CRP enrollment in the chronosequence of CRP fields seeded with native perennial grasses (Native-Early, Mid, and Late), and CRP fields seeded with introduced grasses: Bromus inermis (BRIN-Late) and Agropyron intermedium (AGIN-Late), from 2005 to 2007. Chronosequence regression:

$y=-0.86 x+22, r^{2}=0.29$ (forbs); $y=33 \mathrm{e}^{-0.5\left(\frac{x-6.8}{2.3}\right)^{2}}, r^{2}=0.54$ (annual grasses); $y=1.3 x-0.39, r^{2}=0.55$ (seeded perennial grasses); $y=0.50 x-1.3, r^{2}=0.46$ (colonizing perennial grasses).

were absent in CRP fields, except in late fields seeded with native perennial grasses, where they occurred with less than $1 \%$ cover (not shown).

In 2005, there was significantly higher relative canopy cover of $\mathrm{C}_{3}$ species and lower relative cover of $\mathrm{C}_{4}$ species in all CRP fields, except late CRP fields seeded with native perennial grasses, compared to undisturbed SGS (Fig. 3a). Along the

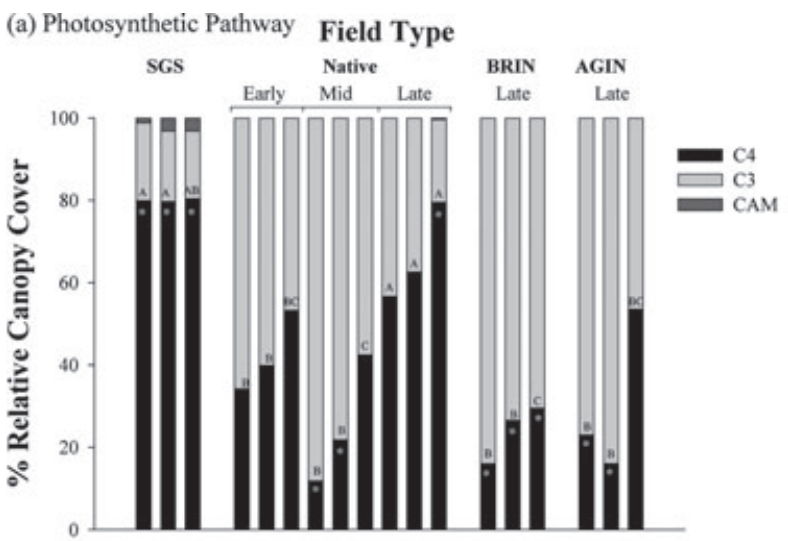

(b) Origin

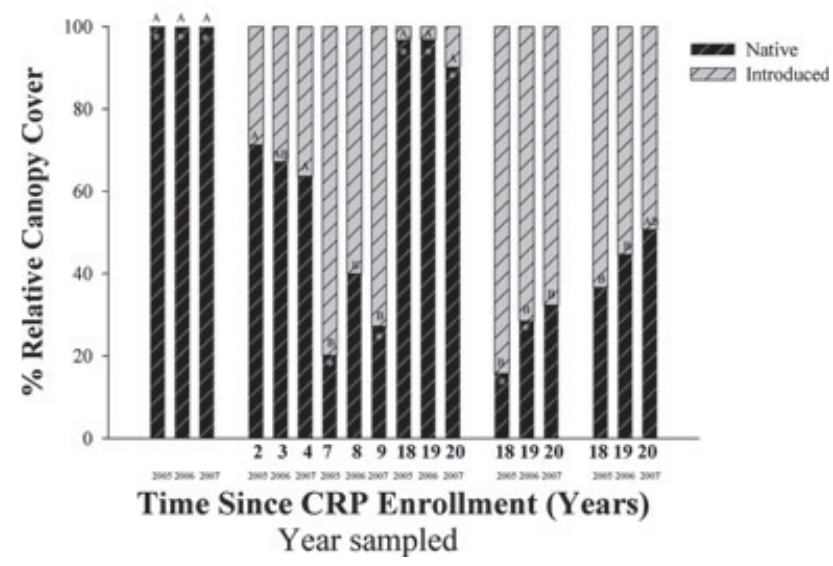

Figure 3. Percent relative canopy cover of plants with $\mathrm{C}_{3}, \mathrm{C}_{4}$, and CAM photosynthetic pathways (a), and species of native and introduced origin (b), in the SGS and in relation to time since CRP enrollment in the chronosequence of CRP fields seeded with native perennial grasses (Native-Early, Mid, and Late), and CRP fields seeded with introduced grasses: Bromus inermis (BRIN-Late) and Agropyron intermedium (AGIN-Late), from 2005 to 2007. Different capital letters designate significant differences (Tukey adjusted $p<0.05$ ) in $\mathrm{C}_{3}$ and $\mathrm{C}_{4}$, and native and introduced species, among field types within the same sampling year and an asterisk (*) designates significant differences $\left(p<0.05\right.$ ) between $\mathrm{C}_{3}$ and $\mathrm{C}_{4}$, and between native and introduced species, within the same field type in a sampling year.

chronosequence, $\mathrm{C}_{3}$ cover was significantly higher in mid CRP fields than late CRP fields. All CRP fields showed a trend of decreasing $\mathrm{C}_{3}$ and increasing $\mathrm{C}_{4}$ relative cover in the 3 years of the study, while undisturbed SGS remained a $\mathrm{C}_{4}$-dominated plant community. Plants with a CAM photosynthetic pathway were only present in undisturbed SGS and late CRP fields seeded with native perennial grasses.

Many CRP fields were composed of significantly more introduced species than undisturbed SGS (Fig. 3b). Mid CRP fields had the highest canopy cover of introduced species along the chronosequence, which were not significantly different from late CRP fields seeded with introduced perennial grasses in all years of the study. There was a negative correlation between seeded native perennial grass canopy cover and introduced Br. tectorum canopy cover $(r=-0.76, p=0.02)$ 


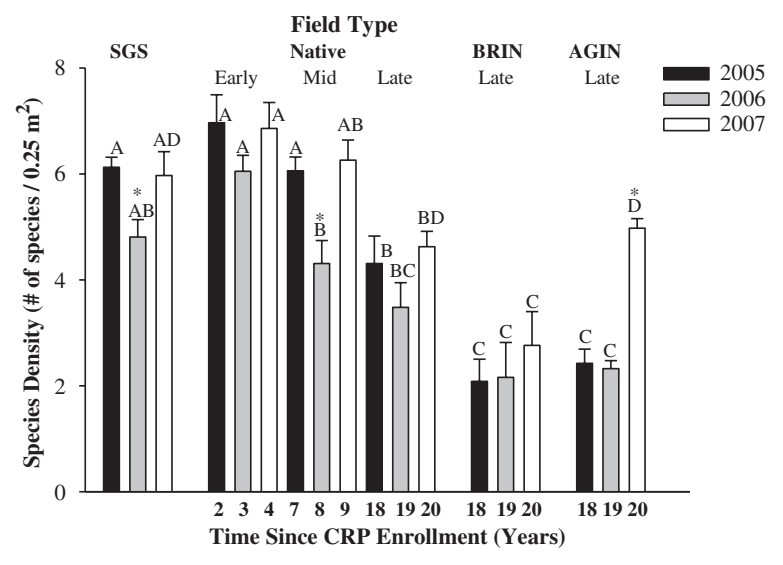

Figure 4. Species density (number of species $/ 0.25 \mathrm{~m}^{2}$ ) in the SGS and in relation to time since CRP enrollment in the chronosequence of CRP fields seeded with native perennial grasses (Native-Early, Mid, and Late), and CRP fields seeded with introduced grasses: Bromus inermis (BRIN-Late) and Agropyron intermedium (AGIN-Late), from 2005 to 2007. Different capital letters designate significant differences (Tukey adjusted $p<0.05$ ) in species density among field types within the same sampling year. An asterisk $(*)$ designates a significant (Tukey adjusted $p<0.05)$ interannual difference in species density from the other two sampling years within the same field type.

in all mid CRP fields across all years of the study. There was an increase of native species cover in late CRP fields seeded with introduced perennial grasses over the course of the study. Late CRP fields seeded with native perennial grasses had more than $90 \%$ relative cover of native species, and were not significantly different than undisturbed SGS.

Species density (number of species $/ 0.25 \mathrm{~m}^{2}$ ) decreased along the chronosequence in all years of the study (Fig. 4). Late CRP fields seeded with introduced perennial grasses had significantly lower species density than late CRP fields seeded with native perennial grasses in 2005, but were not lower in 2006 and only late fields seeded with Br. inermis were lower in 2007. Species density in undisturbed SGS was not significantly different from CRP fields seeded with native perennial grasses, except in 2005 when it was significantly higher. Interannual changes in species density in CRP fields seeded with native perennial grasses and undisturbed SGS were correlated to annual precipitation $(r=0.43, p=0.009)$. There was significantly higher species density in late CRP fields seeded with Agropyron intermedium in 2007 compared to the other two sampling years.

\section{Discussion}

The dominance by forbs and annual grasses in early and mid CRP fields was consistent with our model of plant community dynamics. The success of these functional types may be attributed to their prolific seed production, rapid dispersal mechanisms, and high abundance in SGS seedbanks (Coffin \& Lauenroth 1989). An inverse relationship between forbs and perennial grass canopy cover suggests that the increased dominance of perennial grasses inhibited forb cover, which has been indirectly shown through perennial grass removal experiments in the SGS (Munson \& Lauenroth 2009). High annual precipitation may allow forb species to escape the competitive suppression of grasses, as there was not a significant inverse relationship between the two functional types in 2007.

The presence of Bromus tectorum appears to prolong annual grass dominance in restored fields compared to the prediction of the model. Although undisturbed SGS resists Br. tectorum invasion (Bradford \& Lauenroth 2006), restored fields are susceptible until perennial grasses dominate the plant community. Invasion of this introduced annual grass showed high spatial variability, as indicated by a range of less than $1-30 \%$ canopy in CRP fields 4 years after enrollment. This variability was unlikely due to management practices since early restored fields were operated and seeded by the same landowner and there was no weed control in any of the restored fields. Fields may have differed in propagule pressure from neighboring fields. Spatial variability among fields was still high 7 years after CRP enrollment, but all of these fields had more than $25 \% \mathrm{Br}$. tectorum cover. Above average early growing season precipitation in March and April may have contributed to significantly higher cover of this early growing annual grass in mid CRP fields in 2005, relative to the subsequent 2 years. The low cover of annual grasses $(<1 \%)$ in all late CRP fields suggests that perennial grasses may have competitively excluded them. Low Br. tectorum canopy cover even occurred in late CRP fields seeded with introduced grasses, which apparently had more open niche space for invasion with half as much total vegetation canopy cover and lower species richness.

Consistent with our conceptual model, seeded native perennial grasses successfully germinated and reached a canopy cover of $10 \%$ within 4 years of CRP enrollment (3 years after seeding). Although there was low variability among early CRP fields in seeded native perennial grass cover, this may be attributed to similar seeding conditions by the same operator and is not necessarily reflective of similar perennial grass establishment on all early CRP fields, which can have high spatial and temporal variability (McCoy et al. 2001; Bakker et al. 2003). An increase in seeded perennial grass cover of approximately $1 \%$ per year is slow relative to a $10-15 \%$ per year increase reported for cultivated land converted to grasslands in more mesic regions (Baer et al. 2002; Camill et al. 2004). Although seeded native perennial grasses composed a majority of the cover after 18 years, their cover was less than half the perennial grass cover found in undisturbed SGS and was variable among fields, which suggests a lack of full perennial grass recovery. Canopy cover of seeded introduced perennial grasses was one-third of undisturbed SGS, and may not persist over the long-term (Coffin et al. 1996).

Recovery of the dominant perennial shortgrass, Bouteloua gracilis, is of particular importance because it composes $75-90 \%$ of production at most undisturbed sites (Coffin \& Lauenroth 1988). Bouteloua gracilis typically recovers slowly on abandoned cropland (Coffin et al. 1996), but seed availability and competition from perennial plants are not limitations in CRP fields (Coffin \& Lauenroth 1989). Bouteloua gracilis 
increased from $2 \%$ canopy cover in early CRP fields to $8 \%$ in late CRP fields, but late CRP fields had only a quarter of the Bo. gracilis canopy cover compared to undisturbed SGS and there was high variability in canopy cover among fields. This finding confirms that shortgrass recovery can be slow and variable (Coffin et al. 1996), even when they are seeded.

Our conceptual model of plant community dynamics predicted that colonizing perennial grasses would establish after seeded perennial grasses because they were not in the soil seed bank and have high interannual variability in establishment (Costello 1944). The rate of increase of colonizing perennial grass cover is important because it indicates the recovery potential of abandoned fields in the absence of CRP restoration practices. Colonizing perennial grasses were not present in the first 4 years after CRP enrollment, but after 18-20 years increased by over $300 \%$, and replaced seeded perennial grasses in some fields. Colonizing perennial grasses are likely to continue to propagate in fields in which adult plants have become established.

Plant community composition in CRP fields included a high proportion of $\mathrm{C}_{3}$ species, which represented an important physiological and phenological difference from the undisturbed SGS. This difference in composition is important because it has the potential to influence ecosystem processes (Epstein et al. 1999). Model simulations indicate that a change in the seasonal pattern of precipitation can alter the composition of $\mathrm{C}_{3}$ and $\mathrm{C}_{4}$ plants at a decadal time scale in the northernmost part of the SGS (Epstein et al. 1999). We found that within 3 years, all restored fields shifted toward a higher proportion of $\mathrm{C}_{4}$ species despite little interannual variability in the dominance of $\mathrm{C}_{4}$ species in undisturbed SGS. The growth of $\mathrm{C}_{4}$ species was likely enhanced by a shift to high late growing season precipitation in 2006 and 2007.

The near absence of introduced species on undisturbed SGS suggests that they require disturbance to establish (Milchunas \& Lauenroth 1995). Introduced species were present on all early restored fields, but the rate at which they spread in the first 4 years after CRP enrollment was variable (from a $1 \%$ decrease to $17 \%$ increase). Seven years after CRP enrollment, introduced species were high ( $>35 \%$ canopy cover) in all fields, largely due to the presence of Br.tectorum. High Br. tectorum cover in mid CRP fields may have contributed to low relative cover of native species due to depletion of resources (Lowe et al. 2003).

Natural succession on abandoned cropland can result in a gradual accretion of species (Tilman 1990), but seeding perennial grasses following abandonment has resulted in no change (Camill et al. 2004) or a decrease (Burger et al. 1990; Millenbah et al. 1996; McCoy et al. 2001) in species richness through time, presumably due to the increased dominance of seeded perennial grasses. Early stages of plant community development in restored fields included a high coexistence of different plant functional types, which resulted in high species density. Perennial grasses may have competitively suppressed other functional types, which resulted in low species density in late CRP fields. Low propagule availability of certain species of native forbs in restored fields seems likely given that $63 \%$ of the native annual and perennial forbs that occurred in undisturbed SGS were not present in the oldest CRP fields seeded with native perennial grasses.

Species density was lower in fields seeded with introduced perennial grasses than fields seeded with native perennial grasses in 2005. Introduced species can displace native species and reduce species richness (D'Antonio \& Vitousek 1992). Christian and Wilson (1999) found that fields in the northern mixed prairie seeded with Agropyron cristatum, an introduced perennial grass, contained fewer native species, resulting in lower species richness and diversity than fields that had undergone succession to native perennial grasses. Reduction of A. cristatum increased native grass establishment and the richness and canopy cover of other native species, in part due to increased moisture and nitrogen availability (Bakker et al. 2003). Similar mechanisms may limit native species canopy cover in the SGS.

A correlation between annual precipitation and species density in CRP fields seeded with native perennial grasses and undisturbed SGS was largely attributable to annual forb species, which can respond rapidly to changes in water availability (Milchunas et al. 1990). Late CRP fields seeded with introduced perennial grasses had low species density, except in 2007, when species density increased in fields seeded with A. intermedium. Most of the species responsible for high species density in these fields were native. Therefore, it is possible for native species to recolonize fields where introduced species dominated, especially in years when annual precipitation is above the mean.

\section{Conclusions}

Time since CRP enrollment affected plant community composition in restored fields. Early to mid CRP fields were dominated by forbs and annual grasses, which decreased in cover as perennial grasses became established. After 20 years, CRP fields seeded with native perennial grasses had recovered just under half the canopy cover expected based on undisturbed SGS sites, and CRP fields seeded with introduced perennial grasses had recovered about one-third. After 20 years, colonization of CRP fields by native perennial grasses, which depends primarily on seed dispersal, increased from 0 to $10 \%$ canopy cover. These results document that the time required for recovery of CRP fields to be similar in composition and cover to undisturbed SGS will greatly exceed 20 years.

Seed mix determined which perennial grasses dominated the plant community within 18 years, but variable establishment allowed for dominance by plants with different life forms, photosynthetic pathways, and origins. Species density declined in CRP fields as seeded perennial grass canopy cover increased and was lowest in late CRP fields seeded with introduced perennial grasses. Relative differences in cover between species and functional types in these fields were modified by shifts in the amount and seasonality of precipitation. Low mean annual precipitation and the spread of colonizing perennial grasses are likely to affect plant community composition beyond 20 years in CRP fields. 


\section{Implications for Practice}

- Seeding with a native perennial grass mix in formerly cropped CRP fields of eastern Colorado promotes the recovery of perennial vegetation cover and composition to resemble undisturbed SGS.

- Seeding with introduced perennial grass mixes has the potential to restore perennial vegetation cover over the short-term, but slows the recovery of native species richness.

- Restoration practices in semiarid regions should account for low and variable water availability, which can limit potential cover of seeded perennial species and cause rapid shifts in plant community composition.

- Introduced annual species, such as Bromus tectorum, can be persistent and prolong perennial grass establishment. Restoration practices, such as the use of cover crops and seeding perennial grasses to the proper depth and spacing can minimize the spread of introduced annuals.

- Although forb species compose most species richness in restored fields, they can decline with increased dominance of perennial grasses. Restoration practices could enhance species richness by using more forb species, a greater number of forb seeds, or seeding portions of the field with a high forb:grass seed ratio.

\section{Acknowledgments}

This project was made possible by Weld County CRP landowners, who generously let us work on their land. We thank J. Wicke at NRCS and the SGS-LTER staff for their support. P. Chapman provided statistical advice. Thanks to A. Knapp, N. Hannan, I. Burke, J. Ludwig, and two anonymous reviewers of earlier versions of this article. This research was supported by the Shortgrass Steppe LTER project (National Science Foundation Grant No. 0217631), National Fish and Wildlife Foundation (Grant No. 2006-0094-005), and the Colorado Agricultural Experiment Station (Grant No. 1-57661).

\section{LITERATURE CITED}

Baer, S. G., D. J. Kitchen, J. M. Blair, and C. W. Rice. 2002. Changes in ecosystem structure and function along a chronosequence of restored grasslands. Ecological Applications 12:1688-1701.

Bakker, J. D., S. D. Wilson, J. M. Christian, X. D. Li, L. G. Ambrose, and J. Waddington. 2003. Contingency of grassland restoration on year, site, and competition from introduced grasses. Ecological Applications 13:137-153.

Bradford, J. B., and W. K. Lauenroth. 2006. Controls over invasion of Bromus tectorum: the importance of climate, soil, disturbance, and seed availability. Journal of Vegetation Science 17:693-704.

Burger, L. W. Jr, E. W. Kurzejeski, T. V. Dailey, and M. R. Ryan. 1990. Structural characteristics of vegetation in CRP fields in northern Missouri and their suitability as bobwhite habitat. Transactions of the North American Wildlife and Natural Resources Conference 55:74-83.

Camill, P., M. J. McKone, S. T. Sturges, W. J. Severud, E. Ellis, J. Limmer, C. B. Martin, R. T. Navartil, A. J. Purdie, B. S. Sandel, S. Talukder, and A. Trout. 2004. Community- and ecosystem-level changes in a speciesrich tallgrass prairie restoration. Ecological Applications 14:1680-1694.
Christian, J. M., and S. D. Wilson. 1999. Long-term ecosystem impacts of an introduced grass in the northern great plains. Ecology 80:2397-2407.

Coffin, D. P., and W. K. Lauenroth. 1988. The effects of disturbance size and frequency on a shortgrass community. Ecology 69:1609-1617.

Coffin, D. P., and W. K. Lauenroth. 1989. Spatial and temporal variation in the seed bank of a semiarid grassland. American Journal of Botany 76:53-58.

Coffin, D. P., W. K. Lauenroth, and I. C. Burke. 1996. Recovery of vegetation in a semiarid grassland 53 years after disturbance. Ecological Applications 6:538-555.

Costello, D. F. 1944. Natural revegetation of abandoned plowed land in the mixed prairie association of northeastern Colorado. Ecology 25:312-326.

D'Antonio, C. M., and P. M. Vitousek. 1992. Biological invasions by exotic grasses, the grass/fire cycle, and global change. Annual Review of Ecology and Systematics 23:63-87.

Epstein, H. E., I. C. Burke, and W. K. Lauenroth. 1999. Response of the shortgrass steppe to changes in rainfall seasonality. Ecosystems 2:139-150.

Great Plains Flora Association. 1986. Flora of the Great Plains. University Press of Kansas, Lawrence.

Judd, I. B., and M. L. Jackson. 1939. Natural succession of vegetation on abandoned farmland in the Rosebud soil area of western Nebraska. American Society of Agronomy Journal 39:541-547.

Lowe, P. N., W. K. Lauenroth, and I. C. Burke. 2003. Effects of nitrogen availability on competition between Bromus tectorum and Bouteloua gracilis. Plant Ecology 167:247-254.

McCoy, T. D., E. W. Kurzejeski, L. W. Burger Jr, and M. R. Ryan. 2001. Effects of conservation practice, mowing, and temporal changes on vegetation on CRP fields in northern Missouri. Wildlife Society Bulletin 29:979-987

Milchunas, D. G., and W. K. Lauenroth. 1995. Inertia in plant community structure: state changes after cessation of nutrient enrichment stress. Ecological Applications 5:452-458.

Milchunas, D. G., W. K. Laurenroth, P. L. Chapman and M. K. Kazempour. 1990. Community attributes along a perturbation gradient in a shortgrass steppe. Journal of Vegetation Science 1:375-384.

Milchunas, D. G., O. E. Sala, and W. K. Lauenroth. 1988. A generalized model of the effects of grazing by large herbivores on grassland community structure. American Naturalist 132:87-106.

Millenbah, K. F., S. R. Winterstein, H. Campa III, L. T. Furrow, and R. B. Minnis. 1996. Effects of Conservation Reserve Program field age on avian relative abundance, diversity, and productivity. Wilson Bulletin 108:760-770

Munson, S. M., and W. K. Lauenroth. 2009. Plant population and community responses to removal of the dominant species. Journal of Vegetation Science 20:224-232

Natural Resources Conservation Service. 1991. Technical guide, section IV, standards and specifications, Range Seeding, Colorado. USDA, CO.

Savage, D. A. and H. E. Runyon. 1937. Natural revegetation of abandoned farmland in the central and southern Great Plains. Pages 178-182 in Grassland ecology. Section 1, Fourth International Grassland Congress, Aberystwyth, Great Britain.

Tilman, D. 1990. Constraints and tradeoffs: towards a predictive theory of competition and succession. Oikos 58:3-15.

USDA Farm Service Agency. 2010. U.S. Department of Agriculture Conservation Reserve Program acreage report summary of active and expiring CRP acres by state. ftp://165.221.16.16/crpstorpt/rmepegg/MEPEGGR1.HTM [accessed December 29, 2010].

USDA National Agricultural Statistics Service. 2010. Quick stats: agricultural statistics data base. http://www.nass.usda.gov/Data_and_Statistics/ Quick_Stats [accessed December 29, 2010].

Vinton, M. A., and I. C. Burke. 1995. Interactions between individual plant species and soil nutrient status in short grass steppe. Ecology 76: $1116-1133$.

White, P. S., and S. T. A. Pickett. 1985. Natural disturbance and patch dynamics: an introduction. Pages $3-13$ in S. T. A. Pickett and P. S. White, 
editors. The ecology of natural disturbance and patch dynamics. Academic Press, Orlando, Florida.

\section{Supporting Information}

Additional Supporting Information may be found in the online version of this article:

Appendix S1. Relative percent canopy cover of plant species averaged across all years of study (2005-2007) in undisturbed shortgrass steppe (SGS) and Conservation Reserve Program (CRP) fields seeded with native perennial grasses along a chronosequence (Native-Early [2-4 years after CRP enrollment], Native-Mid [7-9 years], and Native-Late [18-20 years]) and introduced perennial grasses: Bromus inermis (BRIN-Late) and Agropyron intermedium (AGIN-Late) (both 18-20 years after CRP enrollment).

Please note: Wiley-Blackwell is not responsible for the content or functionality of any supporting materials supplied by the authors. Any queries (other than missing material) should be directed to the corresponding author for the article. 